\title{
Rising Inequality and De-democratization
}

\author{
Hany Abdel-Latif ${ }^{a, *}$, Mahmoud El-Gamal $^{\mathrm{b}}$ \\ ${ }^{a}$ Swansea University, UK \\ ${ }^{b}$ Rice University, USA
}

\begin{abstract}
The literature on economic determinants of democratization has identified most importantly the positive effect of economic development and negative effect of income inequality. We confirm these results using more recent data and dynamic panel models. In this regard, the 2018 World Inequality Report has noted that inequality is highest in the Middle East, where it has stayed stable at that high level for the past several decades.
\end{abstract}

Keywords: Inequality, Income Distribution, Democracy

JEL code: $\mathrm{P} 16, \mathrm{O} 10$

\section{Introduction}

Although the literature on democracy deficit in the Middle East, for example, Elbadawi and Makdisi (2010), has touched on the problem of inequality, the effect of inequality on democracy has not been emphasized in this literature. In this regard, the 2018 World Inequality Report (available at https://wir2018.wid.world) has identified the Middle East as the most unequal region in the world, with the top decile capturing $61 \%$ of national income. The report also noted that inequality in the region has persisted at very high levels for the past several decades (pp. 5, 7, 131-7), declining somewhat between 1990 and 2010, and then increasing thereafter. While much of the literature on the Arab democracy deficit has focused on its economic consequences, including the effect of democracy deficit on inequality - see, for example, Elbadawi and Makdisi (2010, p. 75), citing Rodrik (1999) - we highlight in this paper the role of income inequality as one of the most important economic antecedents of democracy or lack thereof.

Our empirical study builds on another early literature, on economic determinants of democracy, which has focused on two main causes, as summarized in Barro (1999). The first cause, as theorized originally by Lipset (1959), is overall economic development, which is measured typically by per capita income, levels and gender balance of primary and higher education attainment, and the like. The second cause, highlighted in Muller (1995), initially to explain some deviations from this previously hypothesized pattern during the 1960s and 1970s, is the level of equality in income-distribution, especially as

${ }^{*}$ Corresponding author: Hany Abdel-Latif (E-mail: h.abdel-latif@swansea.ac.uk), Dept of Economics Swansea University, Swansea UK SA1 8EN TEL: +447429254976. We are grateful to two anonymous referees and participants at the ARD Conference at Stanford University. 
measured in Barro (1999) by the middle-income groups' share of GDP. Finally, and consistently with the findings of Bourguignon and Morrison (1990), Barro (1999) found that high levels of natural resource endowment tend to impact democratization negatively, which is another aspect of the "resource curse" that has long afflicted the Middle East.

According to the classical Kuznets (1955) hypothesis, inequality as a function of per capita income may follow an inverted-U shaped curve. In earlier stages of economic development, the hypothesis stipulates, inequality enhances long term economic growth through the savings channel, because the rich have lower propensities to consume. However, Alesina and Perotti (1996) have highlighted the fact that high levels of inequality can lead to political turmoil, which undermines long-term growth, even in developing countries, through the investment channel. Research in the aftermath of the Arab Spring, including a series of International Monetary Fund staff papers, c.f. Berg and Ostry (2011) and Ostry et al. (2014), has found evidence for both channels of causation and reverse-causation between economic growth and income inequality, which may also be investigated at a variety of national and global scales, following Milanovic (2000).

The aim of this paper is to examine dynamically how the trend in income inequality can explain the trend in democracy scores. Our motivation for pursuing this line of inquiry is the democratization surge immediately following Arab uprisings, which was followed by dramtic reversal. Although our sample covers the periods preceding and following the 2011 uprisings, our focus is not on explaining the role of the middle class or inequality in causing the uprisings, for example as in Diwan (2013). Rather, our aim is to investigate (1) if the effect of income inequality on democracy, which was detected in the earlier panel-data studies, has persisted, and (2) to use dynamic panel methods to investigate the effects of trends in inequality on democratization or de-democratization.

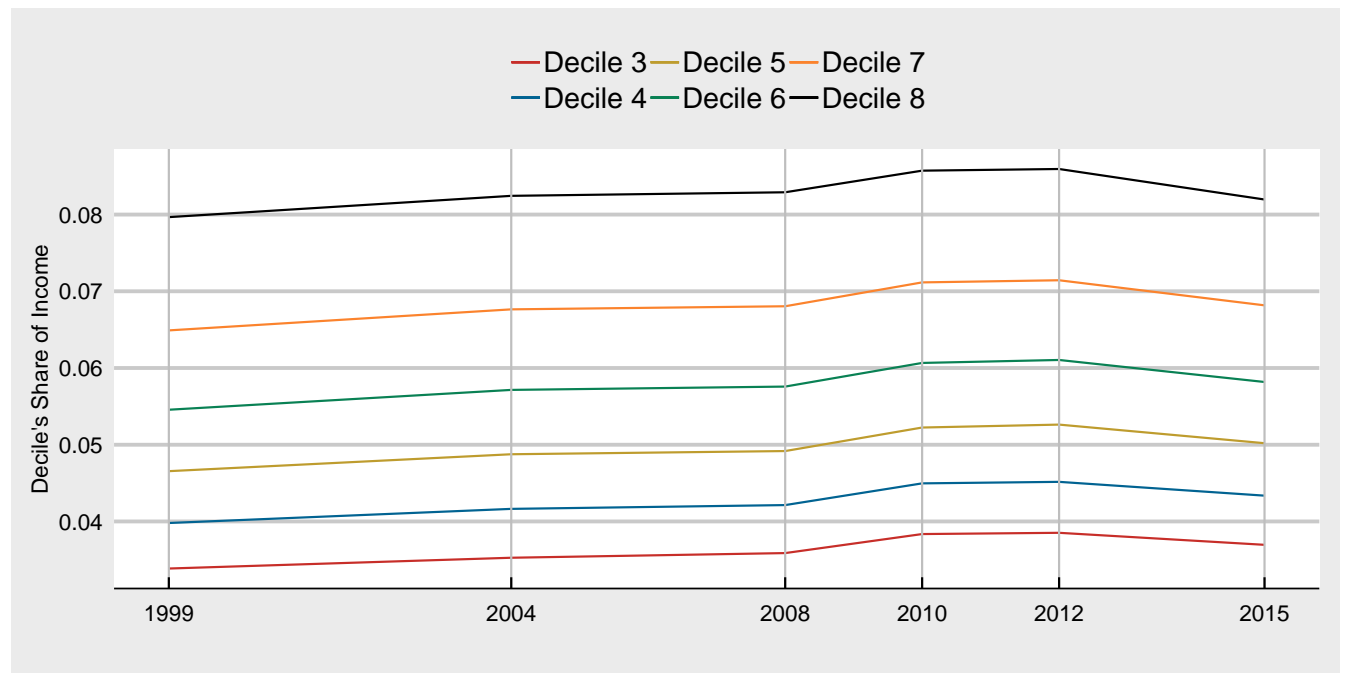

Figure 1: Middle Six Deciles' Share in GDP Egypt)

To illustrate, we highlight the trends and relationships between Egyptian inequality and democracy scores in this introductory section. The reversal in Egyptian income inequality trends is exhibited in Figure 1, which shows the evolution of the six middle 
deciles' shares in income from 1999 to 2015 (using income share data from wdi . world). Those middle income shares (the sum of which was used in Barro (1999) to measure middle class economic empowerment) rose significantly between 1999 and 2012, but then had declined near their 2008 levels by 2015.

Figure 2 offers a comparison of the Egyptian and Turkish joint trends in inequality (measured by the sum of those six deciles' shares in income) and democratization (measured by V-Dem index of electoral democracy development). Although Turkey in general exhibited higher democracy scores for the entire period, both countries have exhibited a strong similarity in de-democratization during their episodes of increasing income inequality, which started in Turkey in 2008 and in Egypt in 2012. This suggests the need to extend Barro's panel data estimation, c.f. Barro (1999, Table 3), of the effect of income inequality on democracy, to allow for dynamic effects of increasing inequality.

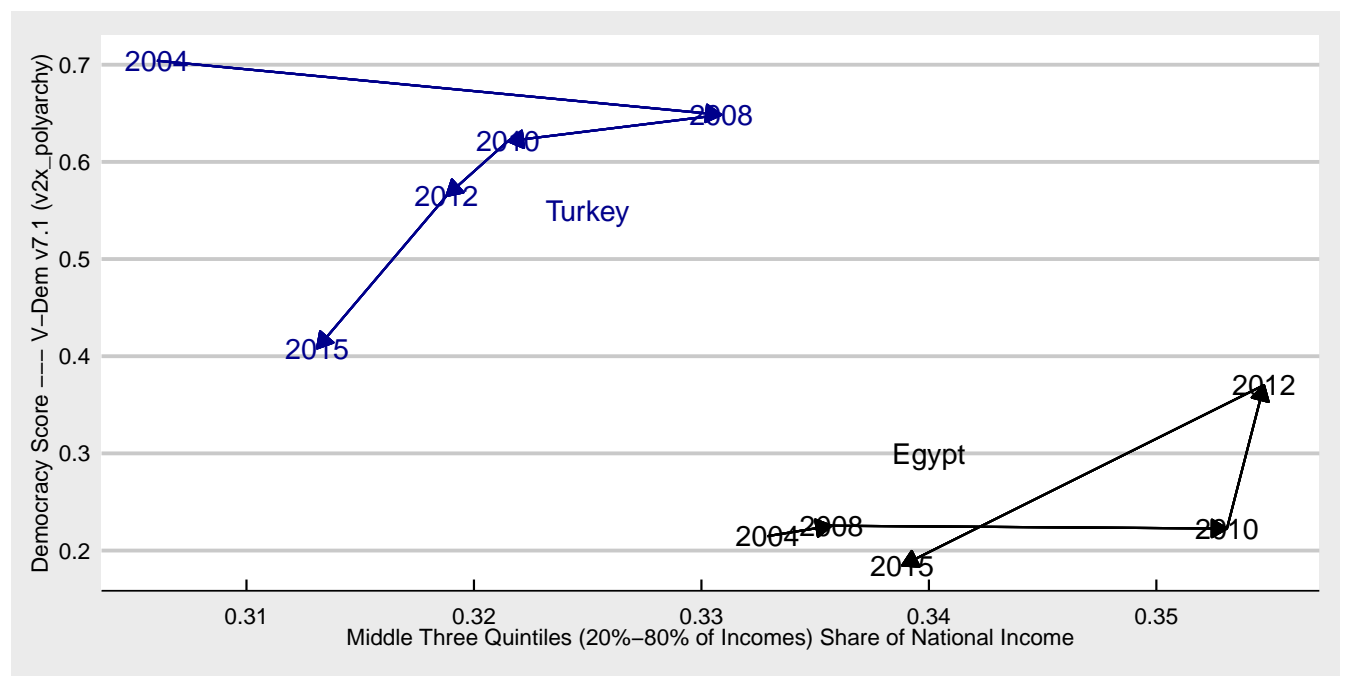

Figure 2: Trajectories for Inequality and Democracy Scores - Egypt \& Turkey

The theoretical literature in political economy supports this dynamic view. Although it may take many years for the economic empowerment of middle income groups to result in greater democratization, short periods of rising income inequality can result in sudden de-democratization, as argued in Tilly (2003). The political economy model of Acemoglu and Robinson (2006) suggests that demands by the general public may force authoritarian regimes to choose between (i) offering superficial concessions, (ii) increasing the scope and severity of their repression, or (iii) sharing some political and economic power by allowing for greater degrees of democratization. As the economic power of the middle class rises with declining inequality, they become less satisfied with superficial concessions, and can punish the regime economically (e.g. strike) for choosing increased repression, thus forcing a bargain on power sharing and democratization.

In Section 2, we describe the panel dataset that we compiled, and report estimates of the relationships between income inequality and various measures of democracy from a large panel of 134 countries over the period 1990-2017, using standard panel fixed and random effects models. Our estimates in that section confirm with more 
extensive data the continued validity of the patterns established in Barro (1999). In Section 3, we complement those earlier results with more dynamic panel data analysis that incorporates lagged dependent and independent variables in a GMM framework. We offer some concluding remarks in Section 4.

\section{Panel Data Estimation of Income Inequality Effects on Democracy}

We compiled an annual dataset for a large panel of 134 countries (listed in Table 5 in the Appendix) during the period 1990-2017 to estimate the effects of each country's level of per capita Gross Domestic Product and income inequality (measured by the Gini coefficient, and lagged in the dynamic specifications) on various democracy scores. The first democracy score that we utilize is the popular "polity" index from the Marshall et al. (2016) database. This score ranges from -10 to 10 (with higher values denoting more democratic institutions). In addition, we utilize a number of detailed measures extracted from the Varieties of Democracy (V-Dem) database in order to investigate different aspects of democratization (the dataset is available at https ://www.v-dem. net/en/).

The main explanatory variables in our static and dynamic panel-data specifications are the Gini coefficient and log of real per capita GDP. Data for these variables and other controls were extracted from the World Bank's World Development Indicators database. Although Barro (1999) had used both Gini coefficients and the middle three quintiles' share of income in his analysis, we used only Gini coefficients in the results reported here due to its wider availability, which enabled us to construct this large panel dataset. Averages and standard deviations of the main variables used in the analysis, shown over countries for every other year, are reported in Table 6.

Table 1 shows the estimation results of basic panel data models using fixed and random effects. The results are consistent with those of Barro (1999): The level of democratization (using all of our selected measures) increases in the level of economic development (measured by log real per capita GDP) and decreases in the level of inequality (measured by the country's Gini coefficient). Moreover the coefficient for inequality is statistically significant, and its magnitude does not vary significantly across the different V-Dem component measures of democratization.

In Table 2, we report fixed effects and random effects estimates for the polity index only, using additional control variables. We get similar results to Barro (1999) for the coefficients of the urbanization rate, which are positive and statistically significant, and the share of fuel in merchandise exports, which are negative and statistically significant. We also include the value added of the manufacturing and agriculture sectors as percentages of GDP, finding that the former is positively correlated with polity scores, while the latter is negatively correlated, and both effects are statistically significant.

Most importantly, the main results reported in Table 1 (and reproduced in Table 2, columns $1 \& 4$ ) remain unchanged after we include these additional control variables. The Hausman tests in Table 1 reject the random effects model in favor of the fixed effects model for all democracy variables. Nonetheless, it is notable that the results in terms 
of sign, magnitude, and statistical significance are very similar for both methods. The Hausman tests with additional controls in Table 2 still reject the random effects model in favor of the fixed effects model for our most encompassing measure of democratization. In the interest of space, we do not report the results of similar regressions for other measures of democracy. The main result obtained in the earlier literature, that democracy declines with inequality and increases with income per capita, continues to hold.

\section{Dynamic Panel Estimation}

Going beyond the standard panel model, we verify in Table 3 that the effect of inequality on democracy continues to be negative and statistically significant even when we account carefully for dynamics. This table shows the results from Generalized Method of Moments (GMM) estimation of a dynamic panel data model with the five-year lag of a country's level of democratization as one of the explanatory variables, together with lagged level of income inequality and contemporaneous log GDP per capita, using the dynamic panel estimator of Arellano and Bond (1991). To deal with the potential bias and inconsistency caused by lagged dependent variables and serially correlated residuals, we used further lags of dependent and explanatory variables as instruments.

The resulting estimates show moderate persistence in all measures of the level of democracy (with a coefficient of the 5-year lagged level of democracy greater than 0.1 and very significant statistically for most measures), and the coefficients for log of real per capita GDP and 5-year lagged Gini coefficients retain their expected signs and statistical significance reported in Table 1. This shows that past levels of inequality have a strong effect on current levels of democracy, as hypothesized in the introduction.

Next, we consider not only the level of past inequality, but also its trend. Table 4 adds to our dynamic analysis a dummy variable for inequality having increased over the past five years, and an interaction term for that dummy variable with the lagged level of inequality. The results for most measures of democracy show that both the level of past inequality and the direction of inequality matter, and the latter may be even more important in terms of magnitude.

\section{Concluding Remarks}

Our results are consistent with modernization theories of democracy as described in Inglehart and Welzel (2005). As we have witnessed in Turkey and Egypt, periods of economic empowerment of the middle classes may drive societies to demand greater voice in the governance of their countries, leading to temporary democratization. However, for countries that have not established strong democratic institutions, it is very easy to revert to de-democratization following episodes of growing income inequality.

We have used the Gini coefficient as our measure of inequality, as has been commonly done in the literature. In this regard, it is well known that the Gini coefficient is most appropriate for measuring changes in the middle range of the income distribution, which is the primary measure of concern in Barro (1999) and this paper. However, the Gini 


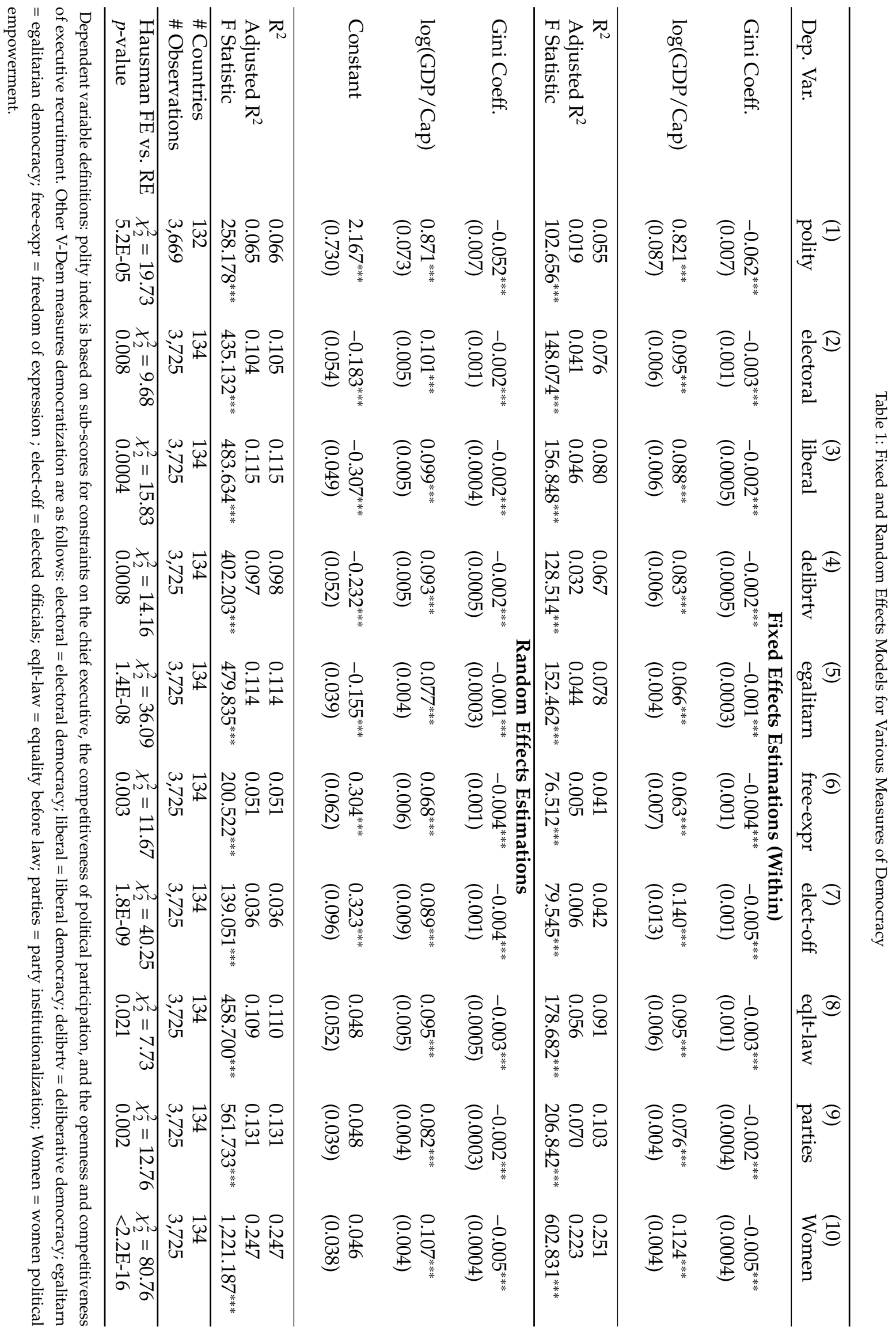




\begin{tabular}{|c|c|c|c|c|c|c|}
\hline & \multicolumn{3}{|c|}{ Fixed Effects } & \multicolumn{3}{|c|}{ Random Effects } \\
\hline & (1) & (2) & (3) & (4) & (5) & (6) \\
\hline Gini Coeff. & $\begin{array}{l}-0.062^{* * *} \\
(0.007)\end{array}$ & $\begin{array}{l}-0.054^{* * *} \\
(0.007)\end{array}$ & $\begin{array}{l}-0.055^{* * *} \\
(0.008)\end{array}$ & $\begin{array}{l}-0.052^{* * *} \\
(0.007)\end{array}$ & $\begin{array}{l}-0.048^{* * *} \\
(0.007)\end{array}$ & $\begin{array}{l}-0.047^{* * *} \\
(0.007)\end{array}$ \\
\hline $\log (\mathrm{GDP} / \mathrm{Cap})$ & $\begin{array}{l}0.821^{* * *} \\
(0.087)\end{array}$ & $\begin{array}{l}0.053 \\
(0.116)\end{array}$ & $\begin{array}{l}0.168 \\
(0.126)\end{array}$ & $\begin{array}{l}0.871^{* * *} \\
(0.073)\end{array}$ & $\begin{array}{l}0.114 \\
(0.102)\end{array}$ & $\begin{array}{l}0.234^{* *} \\
(0.107)\end{array}$ \\
\hline Manuf/GDP & & $\begin{array}{l}0.024^{* * *} \\
(0.008)\end{array}$ & $\begin{array}{l}0.027^{* * *} \\
(0.008)\end{array}$ & & $\begin{array}{l}0.018^{* *} \\
(0.007)\end{array}$ & $\begin{array}{l}0.016^{* *} \\
(0.008)\end{array}$ \\
\hline Agric/GDP & & $\begin{array}{l}-0.036^{* * *} \\
(0.005)\end{array}$ & $\begin{array}{l}-0.031^{* * *} \\
(0.006)\end{array}$ & & $\begin{array}{l}-0.035^{* * *} \\
(0.005)\end{array}$ & $\begin{array}{l}-0.032^{* * *} \\
(0.006)\end{array}$ \\
\hline UrbanPop/Pop & & $\begin{array}{l}0.061^{* * *} \\
(0.007)\end{array}$ & $\begin{array}{l}0.062^{* * *} \\
(0.007)\end{array}$ & & $\begin{array}{l}0.051^{* * *} \\
(0.006)\end{array}$ & $\begin{array}{l}0.050^{* * *} \\
(0.006)\end{array}$ \\
\hline Fuel/MerchExports & & & $\begin{array}{l}-0.011^{* * *} \\
(0.003)\end{array}$ & & & $\begin{array}{l}-0.017^{* * *} \\
(0.003)\end{array}$ \\
\hline Constant & & & & $\begin{array}{l}2.167^{* * *} \\
(0.730)\end{array}$ & $\begin{array}{l}5.738^{* * *} \\
(0.888)\end{array}$ & $\begin{array}{l}4.988^{* * *} \\
(0.936)\end{array}$ \\
\hline Observations & 3,669 & 3,557 & 3,446 & 3,669 & 3,557 & 3,446 \\
\hline$R^{2}$ & 0.055 & 0.095 & 0.093 & 0.066 & 0.101 & 0.105 \\
\hline Adjusted $\mathrm{R}^{2}$ & 0.019 & 0.060 & 0.058 & 0.065 & 0.099 & 0.104 \\
\hline F Statistic & $102.656^{* * *}$ & $71.614^{* * *}$ & $56.816^{* * *}$ & $258.178^{* * *}$ & $397.237^{* * *}$ & $404.935^{* * *}$ \\
\hline $\begin{array}{l}\text { Hausman FE vs. RE } \\
p \text {-value }\end{array}$ & $\begin{array}{l}\chi_{2}^{2}=19.73 \\
5.2 \mathrm{E}-05\end{array}$ & $\begin{array}{l}\chi_{5}^{2}=38.02 \\
3.7 \mathrm{E}-07\end{array}$ & $\begin{array}{l}\chi_{5}^{2}=59.24 \\
6.4 \mathrm{E}-11\end{array}$ & & & \\
\hline
\end{tabular}




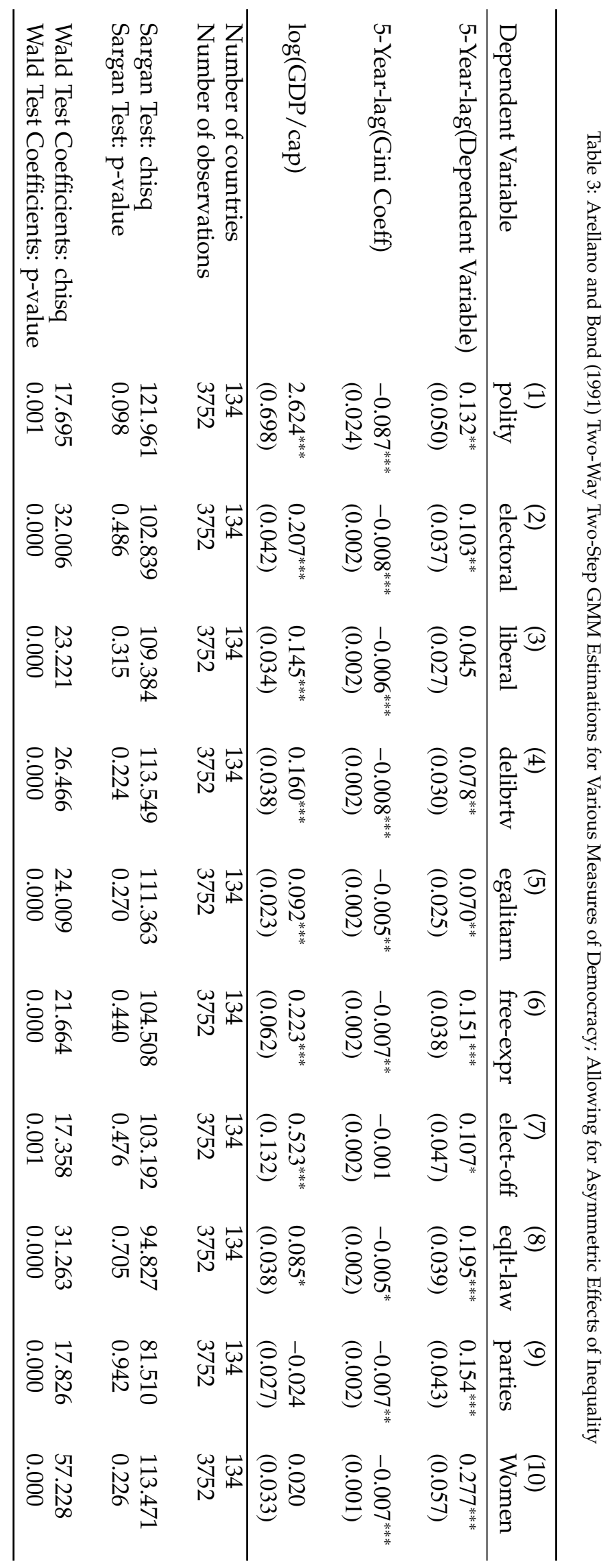




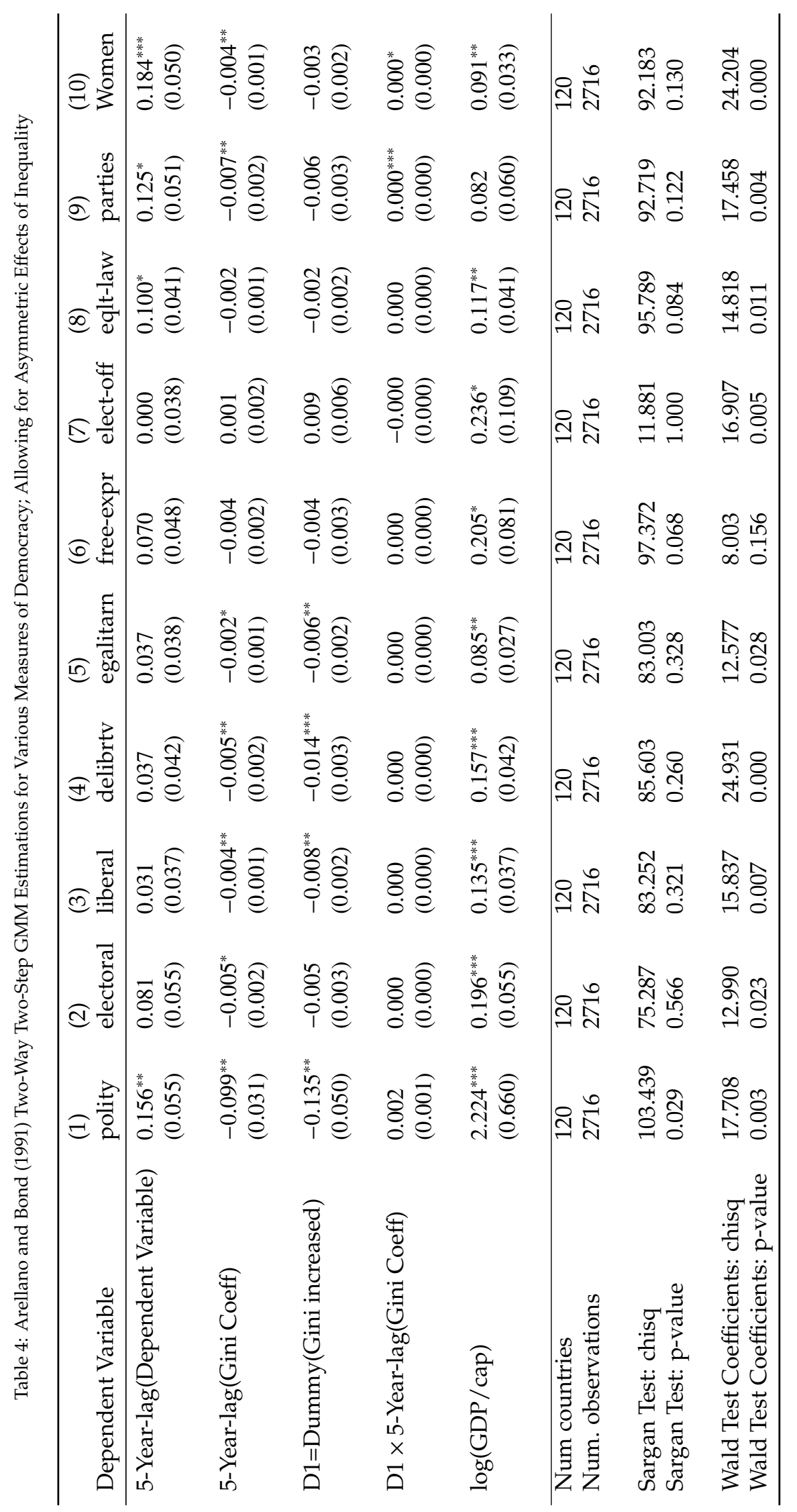


coefficient is not the best measure if we were concerned about changes in the upper tail of the distribution. A more complete analysis would consider the effects of extreme inequality in the tails of income and wealth distributions, as considered in the recent work of many authors who see the global decline of democracy as a consequence of steadily rising extreme inequality, e.g. with special reference to Egypt and the Middle East in Alvaredo and Piketty (2015) and Alvaredo et al. (2017).

A more complete dynamic analysis of the relationship between inequality and democracy would integrate both directions of causation, from greater democracy to less inequality, as investigated by Rodrik (1999), and from lower inequality to more democracy, as investigated by Barro (1999), allowing for feedback effects. Ideally, such an analysis would be coupled with more detailed forecasts of inequality trends for each country. Unfortunately, the latter would require the study of country-level sectoral data that were collected and reported using different methods. Although our analysis falls short of providing the ideally complete dynamic picture of the relationship between inequality and democracy, it has confirmed the importance of considering the direction of causation from increasing inequality to de-democratization.

\section{References}

Acemoglu, D. and Robinson, J. (2006), Economic Origins of Dictatorship and Democracy, Cambridge University Press, New York.

Alesina, R. and Perotti, R. (1996), 'Income distribution, political instability, and investment', European Economic Review 40, 1203-28.

Alvaredo, F., Assouad, L. and Piketty, T. (2017), Measing inequality in the middle east 1990-2016: The world's most unequal region?, Working Paper Series 2017/15, World Wealth and Income Database.

Alvaredo, F. and Piketty, T. (2015), Measuring top incomes and inequality in the middle east, Working paper, Paris School of Economics.

Arellano, M. and Bond, S. (1991), 'Some tests of specification for panel data: Monte carlo evidence and an application to employment equations', Review of Economic Studies 58, 277-97.

Barro, R. (1999), 'Determinants of democracy', Journal of Political Economy 107(6), S158-S183.

Berg, A. and Ostry, J. (2011), Inequality and unsustainable growth: Two sides of the same coin?, Staff Discussion Note SDN/11/08, International Monetary Fund.

Bourguignon, F. and Morrison, C. (1990), 'Income distribution, development and foreign trade: A cross sectional analysis', European Economic Review 34, 1113-32.

Diwan, I. (2013), 'Understanding revolution in the middle east: The central role of the middle class', Middle East Development Journal 5(1), 1-30.

Elbadawi, I. and Makdisi, S., eds (2010), Democracy in the Arab World: Explaining the Deficit, Routledge, IDRC.

Inglehart, R. and Welzel, C. (2005), Modernization, Cultural Change, and Democracy: The Human Development Sequence, Cambridge University Press, New York.

Kuznets, S. (1955), 'Economic growth and income inequality', The American Economic Review 45(1), 1-28.

Lipset, S. (1959), 'Some social requisites of democracy: Economic development and political legitimacy', The American Political Science Review 53(1), 69-105.

Marshall, G. M., Keith, J. and Robert, G. T. (2016), 'Polity iv project: Political regime characteristics and transitions, 1800-2009', Dataset Users' Manual. Center for International Development and Conflict Management, University of Maryland .

Milanovic, B. (2000), Equality, Participation, Transition, number 4, Palgrave McMillan, London, chapter Determinants of Cross-Country Income Inequality: An 'Augmented' Kuznets Hypothesis, pp. 48-79.

Muller, E. (1995), 'Economic determinants of democracy', American Sociological Review 60(6), 966-82.

Ostry, J., Berg, A. and Tsangarides, C. (2014), Redistribution, inequality, and growth, Staff Discussion Note SDN/14/02, International Monetary Fund.

Rodrik, D. (1999), 'Democracies pay higher wages', Quarterly Journal of Economics 114(3), 707-738.

Tilly, C. (2003), 'Inequality, democratization, and de-democratization', Sociological Theory 21(1), 37-43. 


\section{Appendix}

Table 5: List of Countries In Panel Data Analysis

\begin{tabular}{|c|c|c|c|}
\hline Albania & Algeria & Angola & Argentina \\
\hline Armenia & Australia & Austria & Azerbaijan \\
\hline Bangladesh & Belarus & Belgium & Benin \\
\hline Bhutan & Bolivia & Bosnia and Herzegovina & Botswana \\
\hline Brazil & Bulgaria & Burkina Faso & Burundi \\
\hline Cabo Verde & Cameroon & Canada & Central African Republic \\
\hline Chad & Chile & China & Colombia \\
\hline Comoros & Congo, Dem. Rep. & Costa Rica & Cote d'Ivoire \\
\hline Croatia & Cyprus & Czech Republic & Denmark \\
\hline Djibouti & Dominican Republic & Ecuador & Egypt, Arab Rep. \\
\hline El Salvador & Estonia & Eswatini & Ethiopia \\
\hline Fiji & Finland & France & Gabon \\
\hline Gambia, & Georgia & Germany & Ghana \\
\hline Greece & Guatemala & Guinea & Guinea-Bissau \\
\hline Honduras & Hungary & Iceland & India \\
\hline Indonesia & Iran, Islamic Rep. & Iraq & Ireland \\
\hline Israel & Italy & Jamaica & Jordan \\
\hline Kazakhstan & Kenya & Kyrgyz Republic & Lao PDR \\
\hline Latvia & Lesotho & Liberia & Lithuania \\
\hline Madagascar & Malawi & Malaysia & Maldives \\
\hline Mali & Mauritania & Mauritius & Mexico \\
\hline Moldova & Mongolia & Montenegro & Morocco \\
\hline Mozambique & Namibia & Nepal & Netherlands \\
\hline Nicaragua & Niger & Nigeria & Norway \\
\hline Pakistan & Panama & Papua New Guinea & Paraguay \\
\hline Peru & Philippines & Poland & Portugal \\
\hline Romania & Russian Federation & Rwanda & Senegal \\
\hline Serbia & Sierra Leone & Slovak Republic & Slovenia \\
\hline Solomon Islands & South Africa & Spain & Sri Lanka \\
\hline Sweden & Switzerland & Tajikistan & Tanzania \\
\hline Thailand & Timor-Leste & Togo & Tunisia \\
\hline Turkey & Uganda & Ukraine & United Kingdom \\
\hline United States & Uruguay & Uzbekistan & Venezuela, RB \\
\hline Yemen, Rep. & Zambia & & \\
\hline
\end{tabular}




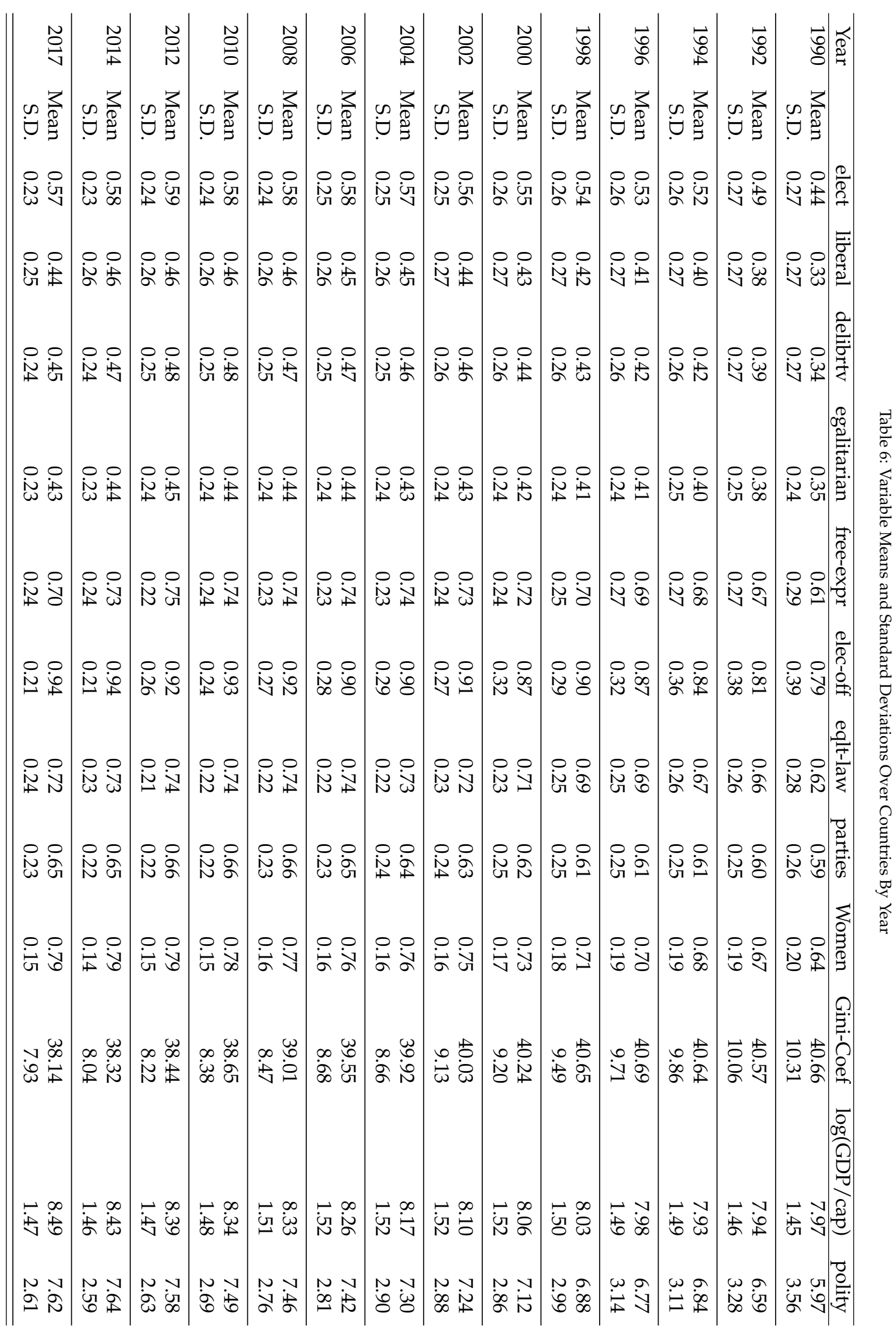

